9.

\title{
„JEDAN NARODNI JEZIK I JEDAN JEDINSTVEN KNJIŽEVNI JEZIK“. ANKETA LETOPISA MATICE SRPSKE I SASTANAK U NOVOM SADU
}

\section{Krešimir Mićanović}

UDK: 81'26(497.1)“1954“

Izvorni znanstveni članak

Sažetak: Novosadski dogovor prijelomni je događaj u oblikovanju zajedničke, centralističke jezične politike za područje četiriju središnjih jugoslavenskih narodnih republika - Hrvatske, Bosne i Hercegovine, Crne Gore i Srbije. Sudionici sastanka u Novom Sadu u prosincu 1954. zaključili su da je narodni jezik Srba, Hrvata i Crnogoraca jedan jezik te da je stoga i književni jezik koji se razvio na njegovoj osnovi oko dvaju glavnih središta, Beograda i Zagreba, jedinstven, s dvama izgovorima, ijekavskim i ekavskim. Na osnovi anketnih priloga i transkripta s novosadskog skupa analiziraju se stavovi hrvatskih i srpskih jezikoslovaca, književnika i kulturnih radnika o ,jednom narodnom jeziku“ i ,jedinstvenom književnom jeziku“. Na korpusu tekstova pokazuje se da se jezično pitanje sredinom 1950-ih vrednuje kao političko, da su se u kakofonijskoj raspravi o jeziku mogli čuti pojedinačni i (posve) manjinski glasovi koji su na različite načine poništavali dogovorenu novosadsku formulu: jedan književni jezik (u nazivu kojega se navodi srpsko i hrvatsko ime) = tri naroda = četiri narodne republike. Novosadski dogovor služio je kao normativan i čvrst jezičnopolitički okvir desetak godina, a rad na provedbi novosadskih zaključaka zapet će u drugoj polovici 1960-ih. Matica hrvatska 1970. i službeno prekida suradnju s Maticom srpskom, a hrvatski jezikoslovci i književnici okupljeni u svojim strukovnim društvima u proljeće 1971. i formalno su se odrekli sporazuma postignutog u Novom Sadu.

Ključne riječi: Novosadski dogovor, „Anketa o pitanjima srpskohrvatskog jezika i pravopisa“, jezična politika, književni jezik, pravopis 
I.

$[?$

poslijeratnom razdoblju višejezične i višenacionalne jugoslavenske federacije oblikovan je jezičnopolitički okvir u kojemu nijednom jeziku de iure nije dodijeljen status državnog jezika, a u parlamentarnoj praksi potvrđeno je razlikovanje četiriju jezika jugoslavenskih naroda - hrvatskoga, srpskoga, slovenskoga i makedonskoga. Hrvatski i srpski jezikoslovci neovisno jedni o drugima određuju režim jezičnog standarda, što je u prvom redu značilo, kada je riječ o kodificiranim standardnojezičnim priručnicima, da hrvatskoj ortografskoj praksi kao normativni orijentir služi Pravopis hrvatskoga ili srpskoga jezika Dragutina Boranića, a srpskoj Pravopis srpskohrvatskog književnog jezika Aleksandra Belića. Poslijeratno jezičnopolitičko razdoblje, koje su hrvatski jezikoslovci retrospektivno prikazivali u ružičastim bojama, ${ }^{1}$ u jezičnopolitičkom smislu završava sredinom 1950-ih. Trodnevni sastanak u Novom Sadu održan u prosincu 1954. godine, rezultat kojega su zaključci što su obvezali hrvatske i srpske jezikoslovce na izradu temeljnih standardnojezičnih priručnika, prijelomni je događaj u oblikovanju zajedničke, centralističke jezične politike za područje četiriju središnjih jugoslavenskih narodnih republika - Hrvatske, Bosne i Hercegovine, Crne Gore i Srbije.

\section{2.}

Novosadski sastanak završni je čin „Ankete o pitanjima srpskohrvatskog jezika i pravopisa“ koju je u proljeće 1953. pripremila redakcija Letopisa Matice srpske. U svibnju je upućeno anketno pismo nizu „najistaknutijih srpskih i hrvatskih književnika, naučnika, političkih i javnih radnika“ s ciljem da se čuje njihovo mišljenje „o problemima jezika, pravopisa i rečnika“.2 Prvi anketni prilog i pismo objavljeni su u rujanskom svesku Letopisa te 1953. godine, a posljednji prilog u zadnjem svesku za 1954. godinu. U tom su razdoblju, u petnaest brojeva, objavljena 42 anketna odgovora: prilozi Udruženja prevodilaca Srbije, Društva prevodilaca Hrvatske te 40 autorskih tekstova. ${ }^{3}$

1 Podrobnije o poslijeratnom razdoblju v. Krešimir MićAnović, "The spirit of AVNOJ in language policy’: language policy from the end of World War II to mid-1950s in Yugoslavia and Croatia“, Socjolingwistyka, 32/2018, 23-37.

2 Živan Milisavac, odgovorni urednik Letopisa, u uvodnom referatu na sastanku u Novom Sadu: „Pismo je upućeno u maju (svega nekolicina je pozvata naknadno, u septembru)“, v. Letopis Matice srpske, 131/1955, knj. 375, sv. 1, 8. Citati iz pisma: Redakcija Letopisa Matice srpske, „Anketa o pitanjima srpskohrvatskog jezika i pravopisa“, Letopis Matice srpske, 129/1953, knj. 372, sv. 3, 125.

3 Prema podacima Živana Milisavca anketno pismo razaslano je na 111 adresa, a odgovorila je tek trećina. Odazvalo se njih 36: iz Beograda 11 (pozvano 55), Zagreba 19 (pozvano 44), Sarajeva 3 (pozvano 4), Splita 1 (pozvano 3), Opatije 1, Novog Sada 1 (pozvano 2). Uredništvo je primilo i 17 „odgovora od raznih lica“, a od tih „izvan kruga pozvanih“ objavljena su četiri priloga, v. Letopis Matice srpske, 131/1955, knj. 375, sv. 1, 8, 15. Prilozi su objavljivani redom kojim su stizali i pismom kojim su napisani (v. Letopis Matice srpske, 129/1953, knj. 372, sv. 3, 126): M[ihailo] Stevanović, A[leksandar] Belić, Joža Horvat, Stanislav Vinaver, Josip Smodlaka, P[etar] Skok, Božidar Kovačević, Milija Stanić, J[ovan] Vuković, Đuza Radović, Marko Marković, Radovan Lalić, Svetozar Matić, M[irko] Božić, Vojin Jelić, Antun Barac, Gustav Krklec, M[ate] Hraste, M[arin] Franičević, Ivo Frangeš, Vladan Desnica, Jordan M. Molović, M[iodrag] S. Lalević, Slavko Kolar, Ilija Kecmanović, Nada Senić, Julije Benešić, Ljudevit Jonke, Slavko Pavešić, M[iloš] S. Moskovljević, Josip Badalić, Josip Hamm, Viktor Car Emin, Fran Tućan, Jure Kaštelan, Slavko Ježić, Marijan Jurković, Novak Simić, Svetislav Marić, Borivoje Nedić. 
U razaslanom anketnom pismu redakcija Letopisa objašnjava da neće „postavljati pitanja na koja treba dati neposredan odgovor", kao što je to učinjeno u anketi slovenskog časopisa Veda (1912), ${ }^{4}$ da neće napisati ni poseban članak kojim bi „odredila svoj stav prema tim pitanjima“, kao što je to učinio Jovan Skerlić pri pokretanju „Ankete o južnom ili istočnom narječju u srpsko-hrvatskoj književnosti“ (1914). ${ }^{5}$ Redakcija je ipak istaknula četiri teme: pravopis („,n]edavno je u našoj javnosti bilo potegnuto pitanja pravopisa“), pismo „(ćirilica - latinica)“, „narečje“ i stvaranje rječnika književnog jezika „(srpskog i hrvatskog, ili srpskohrvatskog)“. ${ }^{6}$ Premda uredništvo nije napisalo poseban članak poput Skerlićeva, posve je jasno u pismu artikuliralo vlastiti stav - približan skerlićevskom idealu ekavskoga književnog jezika i latinice kao općeg pisma.

Mi ovde ipak ne možemo da ne podvučemo koliko cenimo sve one napore u daljoj i bližoj prošlosti koji su išli ka uklanjanju razlika, naročito veštačkih, u srpskohrvatskom jeziku i vodili ka sve većem zbližavanju i čvršćem jedinstvu, kao što je bio poznati Književni dogovor u Beču 1850 godine; kao što su navedene ankete; kao što je prihvatanje ekavštine u nekim hrvatskim časopisima u Zagrebu (Vihor, 1914, zatim Krležin Plamen posle Prvog svetskog rata) pa čak i štampanje zbirki stihova ekavštinom (A. B. Šimić, Cesarić itd.); kao što je, s druge strane, štampanje latinicom časopisa u Beogradu (Stožer, Naša stvarnost, Umetnosti i kritika itd.) i knjiga (biblioteka Nolit); kao što je zajedničko izdavanje publikacija (Srpskohrvatski almanah pre, časopis Danas posle Prvog svetskog rata), itd. itd. ${ }^{7}$

Na sastanku u Novom Sadu održanom od 8. do 10. prosinca 1954. podnesen je referat o rezultatima ankete - zadnji anketni prilog objavljen je u prosinačkom svesku Letopisa Matice srpske za 1954. - a „posle diskusije formulisan je stav učesnika konferencije o problemima jezika istaknutim u anketi i diskusiji “ ${ }^{8}$ Redakcija časopisa odgovornost i zasluge za sazivanje konferencije nije pripisala sebi, nego je preuzela ulogu onog koji tek ispunjava želje i zahtjeve drugih. Naime, s obzirom na to da je „[j]edan deo učesnika“, kako je objašnjeno, „naročito podvukao potrebu sazivanja konferencije“, redakcija je, odazivajući se glasu onih koji su u prilozima ,insistirali na dogovoru“, „umolila izvestan broj najpozvanijih stručnjaka za pitanja jezika kao i jedan deo srpskih i hrvatskih književnika da se sastanu i

4 „Anketa o jezikovnem približevanju Jugoslovanov“, u kojoj je postavljeno šesnaest pitanja, izišla je u II. godištu (1912) časopisa Veda, dvomjesečnika za znanost i kulturu, a anketni su prilozi objavljivani u III. godištu (1913).

5 Jovan Skerlić najprije je objavio svoje predavanje „Istočno ili južno narečje?“ u kojem je istaknuo „da istočno, ekavsko narečje, treba da postane književno narečje srpsko-hrvatsko" te predviđao da će za trideset, četrdeset ili pedeset godina, ,kada srpsko-hrvatski narod bude nacionalno obezbeđen [...] latinica postati opšta književna azbuka“ (Jovan Skerlić, „Istočno ili južno narečje“, Srpski književni glasnik, XXXI/(16. 11.) 1913, br. 10, 756-770 + XXXI/ (1. i 16. 12.) 1913, br. 11 i 12, 865, 872). Nakon toga uputio je kao urednik Srpskog književnog glasnika koncem 1913. anketno pismo ,izvesnom broju pisaca i javnih radnika na Slovenskom Jugu“ (Srpski književni glasnik, XXXII/ (16. 1.) 1914, br. 2, 114). Anketni prilozi objavljivani su od 16. 1. do 1. 4. 1914. u Srpskom književnom glasniku, XXXII/1914.

6 Redakcija rabi narječje u značenju 'govor', što bi danas bilo posve pogrešno, v. ReDAKCIJA Letopisa Matice srpske, „Anketa o pitanjima srpskohrvatskog jezika i pravopisa“, 126.

7 Isto.

8 Letopis Matice srpske, 131/1955, knj. 375, sv. 1, 3. Redakcija Letopisa smatra da je sastanak „književnika i jezičkih stručnjaka“ u Novom Sadu „bio logičan i neophodan završetak ankete“, odnosno da je anketa završila 10. 12. 1954. donošenjem zaključaka (Isto, 123). 
pretresu zaključke koji su izvučeni iz ankete i razmotre mogućnost rešavanja onih pitanja koja su u anketi istaknuta kao hitna"?

Sudionici sastanka skup su okončali donošenjem i potpisivanjem teksta zaključaka ${ }^{10} \mathrm{u}$ kojem su ustvrdili da je narodni jezik Srba, Hrvata i Crnogoraca jedan jezik, odnosno da je književni jezik jedinstven (prva točka), da je u nazivu jezika u službenoj upotrebi nužno istaknuti oba njegova dijela (druga točka), da su oba pisma (treća točka) i oba izgovora (četvrta točka) ravnopravna. U zaključcima se ustvrđuje i nužnost izrade temeljnih standardnojezičnih priručnika: izrada suvremenog rječnika književnog jezika (peta točka), terminologija (šesta točka), pravopis (sedma točka). U osmoj točki potpisnici pozivaju da se stane „na put postavljanju veštačkih prepreka u prirodnom i normalnom razvitku hrvatskosrpskog književnog jezika“, ističu da treba spriječiti „štetnu pojavu samovoljnog prevođenja tekstova“. ${ }^{11} \mathrm{Na}$ koncu se navodi tko će odrediti članove komisije za izradu pravopisa, odnosno s kime bi trebalo surađivati u izradi terminologije (deveta točka), zatim da će Matica srpska zaključke dostaviti saveznoj vladi i vladama četiriju narodnih republika, sveučilištima u Beogradu, Zagrebu i Sarajevu, akademiji u Zagrebu i Beogradu, Matici hrvatskoj te ih objaviti u dnevnim listovima i časopisima (deseta točka). ${ }^{12}$

3 .

Povjesničari pedesete u Jugoslaviji opisuju kao razdoblje u kojemu s jedne strane dolazi do postupne decentralizacije i debirokratizacije dotada jako centralizirane države ${ }^{13}-$ drža-

$9 \quad$ Isto. Redakcija je na skup pozvala 23 jezikoslovca i književnika iz Beograda, Zagreba i Sarajeva: iz Beograda 9, odazvalo se 8 (Ivo Andrić, Aleksandar Belić, Marijan Jurković, Miloš Đurić, Radovan Lalić, Miloš M. Moskovljević, Đuza Radović, Mihailo Stevanović; nije se odazvao Milan Bogdanović); iz Zagreba 12, odazvalo se 7 (Marin Franičević, Mirko Božić, Josip Hamm, Mate Hraste, Ljudevit Jonke, Zdenko Škreb, Jure Kaštelan; pismeno su izvijestili Antun Barac i Miroslav Krleža „da ne mogu prisustvovati“, a za Stjepana Ivšića, Gustava Krkleca i Petra Šegedina „saznali smo od prisutnih drugova iz Zagreba da nisu mogli doći zbog bolesti“), iz Sarajeva 2 (Jovan Vuković i Marko Marković). Matica srpska, organizator skupa, odredila je da će sudjelovati njezinih 8 članova - Veljko Petrović, Svetislav Marić, Miloš Hadžić, Krešimir Georgijević, Živojin Boškov, Živan Milisavac, Mladen Leskovac, Boško Petrović - tako da se na konferenciji okupilo 25 sudionika, v. Letopis Matice srpske, 131/1955, knj. 375, sv. 1, str. 7.

10 Zaključke je potpisalo 25 sudionika skupa, a naknadno je redakcija zamolila niz pojedinaca „da svoju saglasnost izraze potpisivanjem teksta“. U konačnici je redakcija prikupila 63 naknadna potpisa najvećim dijelom književnika, sveučilišnih profesora i jezikoslovaca (Isto, 123-125). Štiklec iz biografije jednoga potpisnika: Miroslav Krleža, nije se odazvao anketnom pozivu, nije došao u Novi Sad, no jedan je od naknadnih potpisnika. Opravdavao se 1970. godine, naravno ne javno, da je tada bila takva situacija da je morao potpisati, ,i toga se danas stidim“, v. Enes ČENGIĆ, S Krležom iz dana u dan (1956-1975). Balade o životu koji teče, Zagreb 1985, 40. Milisavac, koji je uz ostale i Krleži donio zaključke na potpis, nije se dao impresionirati Čengićevim zapisom: „Krleža je potpisao bez reči. Koga i čega se plašio? Zašto ih je morao potpisati? Zašto je morao potpisati Deklaraciju o hrvatskom jeziku? Mogu reći da su svi kojima sam podneo Zaključke dali rado svoj potpis“, Živan MilisavaC, „O Novosadskom dogovoru“, NIN (Beograd), br. 1900, 31. 5. 1987, 4.

11 Letopis Matice srpske, 131/1955, knj. 375, sv. 1, 122.

12 Zaključke je formulirala posebna komisija - izabrana na samu početku rada skupa u sastavu Mirko Božić, Mate Hraste (predsjednik), Ljudevit Jonke, Radovan Lalić, Mihailo Stevanović, Miloš M. Moskovljević, Jovan Vuković i Živan Milisavac - no o njima se raspravljalo te su u konačnici usvojeni ponešto izmijenjeni (transkript te rasprave o zaključcima nije objavljen u Letopisu): nakon što se „razvila diskusija oko izvesnih formulacija“, sudionici skupa složili su se „i u formulisanju pojedinih tačaka Zaključaka“, Letopis Matice srpske, 131/1955, knj. 375, sv. 1, 17, 121.

13 Ivo Goldstein, Hrvatska 1918-2008, Zagreb 2008, 417, 471. 
ve koja je u poslijeratnim godinama „lažna federacija“, 14 „unitarna država pod vladavinom centralizirane $\mathrm{KP}^{\text {“15 }}$ - $s$ druge strane kao godine u kojima je u fazi socijalističkog jugoslavenstva pokrenut niz projekata s ciljem unapređenja ,jugoslovenskog jedinstva“. ${ }^{16}$ Pedesete se percipiraju kao razdoblje vrhunca jugoslavenstva i jugoslavenske nacionalne svijesti, no službena politika Komunističke partije Jugoslavije nije bila stvaranje ,jedinstvene jugoslovenske nacije“, ${ }^{17}$ u tim se godinama „u sklopu afirmiranja ideje socijalističkog jugoslavenstva" ukidaju manjinske institucije i društva jugoslavenskih naroda izvan svojih matičnih republika. ${ }^{18}$

Novosadski dogovor smješta se u taj širi politički kontekst, no pritom se uzima u obzir tadašnje socijalističko jugoslavenstvo, a posve ostavlja po strani da se u razdoblju postupne decentralizacije države radi na stvaranju centralne jezične politike za područje četiriju tada narodnih republika federalne Jugoslavije. Jezičnopolitički procesi u poslijeratnom desetljeću nisu kongruentni s općim procesom decentralizacije „lažne federacije“, odnosno ti se procesi ne mogu mehanički prenijeti na područje jezične politike. ${ }^{19}$ Novosadski se dogovor dakle interpretira kao „deo politike razvoja 'socijalističkog jugoslovenstva' ", ${ }^{20}$ odnosno kao izraz dominantne političke volje. ${ }^{21}$ Izvorište inicijative Matice srpske pojedini lingvisti retrospektivno vide u tome da je „posvuda (...) vladalo uvjerenje, i među lingvistima i u javnosti“ da se četiri naroda služe jednim jezikom, no i da je takvo uvjerenje bilo poduprto „ideologijom i politikom 'socijalističkog zajedništva', kao svojevrsnim izrazom unitarizam“. ${ }^{22}$

U poslijeratnom su razdoblju, navodi Đilas u poglavlju naslovljenom „Posleratno jugoslovenstvo", profesionalne, kulturne, umjetničke, znanstvene i sportske organizacije obično bile organizirane na razini republika, ali su pritom , uvek imale neku vrstu uticajne 'centralne kancelarije' u Beogradu“. ${ }^{23} \mathrm{U}$ takav se obrazac funkcioniranja poslijeratnih republičkih organizacija međutim ne mogu uklopiti Matica hrvatska i Matica srpska, dvije kulturne ustanove koje su preuzele na sebe (koja im je dodijeljena?) glavnu zadaću u provedbi novosadskih zaključaka. Nije postojala naime jedna npr. „Matica jugoslavenska“, sa sjedištem u Beogradu, koja bi hijerarhijski bila nadređena hrvatskoj i srpskoj (i slovenskoj). Institucionalizacija je-

14 Ljubodrag Dimić, „Ideologija i kultura u Jugoslaviji 1945-1955“, Istorijski zapisi, LXXII/1999, br. 3-4, 105.

15 Zdenko Radelić, Hrvatska u Jugoslaviji 1945. - 1991. Od zajedništva do razlaza, Zagreb 2006, 250. Slično i: Milan ŠIPKA, „Standardni jezik i jezička politika u Bosni i Hercegovini 1918-1970“, u: Jezik u Bosni i Hercegovini (ur. Svein Mønnesland), Sarajevo - Oslo 2005, 422.

16 Jasna Dragović-Soso, „Spasioci nacije“. Intelektualna opozicija Srbije i oživljavanje nacionalizma, Beograd 2004, 115 .

17 Aleksa Đilas, Osporavana zemlja. Jugoslovenstvo i revolucija, Beograd 1990, 252, 235. Slično i: I. GoldsteIN, Hrvatska 1918-2008, 423, o tome „da vodstvo SKJ nije pomišljalo na stvaranje jugoslavenske nacije“ v. Z. RADELIĆ, Hrvatska u Jugoslaviji, 341.

18 Mario Bara, „Hrvati u Vojvodini“, Hrvatsko nacionalno vijeće u Republici Srbiji (http://www.hnv.org.rs/hrvati_u_ vojvodini.php\#poslijeratno_razdoblje)

19 U literaturi se navodi da je do ustavnih zakona 1953. jaka centralizirana država utjecala „na shvaćanje o nužnosti što brže kulturne homogenizacije“, „[n]apose se nastojalo što više izjednačiti hrvatsko-srpsko jezično područje“, Z. Radelić, Hrvatska u Jugoslaviji, 248. No za jezičnu unifikaciju od presudne su važnosti zbivanja upravo nakon donošenja tih zakona s početka 1953. (no s njima nisu ni na koji način povezana).

I. Goldstein, Hrvatska 1918-2008, 532.

22 M. ŠIPKA, „Standardni jezik i jezička politika u Bosni i Hercegovini“, 422.

23 A. Đilas, Osporavana zemlja, 234. 
zične politike - onako kako je ona zacrtana u tekstu novosadskih zaključaka - provedena je „odozdol“. Srpski jezikoslovci i kulturni radnici okupljeni u Matici srpskoj organizatori su i ankete i trodnevne konferencije, a ne ministarstva prosvjete tradicionalno zadužena za kakvo-takvo reguliranje standardnojezičnog režima (i to u prvom redu samo u školstvu). Pisci anketnih priloga i sudionici konferencije nisu ovlašteni predstavnici institucija u kojima rade ili strukovnih društava kojih su članovi. ${ }^{24}$ Mi nismo, govorili su sudionici skupa, „Zvanična konferencija niti državna ustanova“ (Radovan Lalić), ${ }^{25}$ „nikakav oficijelan skup ili institucija“ (Miloš Hadžić), ${ }^{26}$ skup je zamišljen „kao diskusija ljudi koji imaju sopstvene stavove i mišljenja“ (Krešimir Georgijević), ${ }^{27}$ u Novi Sad su „ljudi dolazili po pozivu (...) kao pojedinci, a ne kao delegati“ (Ljudevit Jonke). ${ }^{28}$ No smatrali su se, naravno, premda skup „nije oficijelno ni od koga imenovan“, pozvanima da kažu svoje mišljenje (Miloš Hadžić), ${ }^{29}$ pisali su o tome da se u Novom Sadu nije raspravljalo „o privatnim stvarima“, nego su sudionici „nastupali tamo u svojoj društvenoj funkciji“ (Radovan Lalić). ${ }^{30}$ Legitimitet sudionicima skupa, ujedno sastavljačima i potpisnicima teksta zaključaka, u prvom redu priskrbljuje njihov osobni autoritet stečen na akademskom ili književnom polju, ali taj je autoritet i neodvojiv od njihova statusa u institucijama ili društvima u kojima profesionalno rade i djeluju.

Izvještavajući o novosadskom skupu čitatelje Vjesnika u srijedu, Dalibor Brozović piše da je na njemu svatko govorio u svoje ime, da nije bilo fronta ni „beogradsko-zagrebačke, ni filološke-književničke“. ${ }^{31}$ Transkript s novosadskog sastanka - objavljen u siječanjskom svesku Letopisa Matice srpske 1955. godine - potvrđuje da nisu postojali polemički rovovi, koje bi se dosljedno moglo razdijeliti na zagrebačke (hrvatske) i novosadsko-beogradske (srpske), ali da su se mogli nerijetko čuti posve razgovijetni glasovi koji su dolazili isključivo s „,beogradskog“ fronta, odnosno sa „zagrebačke“ fronte. Nada Senić, lektorica iz Sarajeva, slušačica na trodnevnoj konferenciji, razočarano je ustvrdila: „Nisam se stvarno nadala da će se ovdje čuti 'mi', 'vi' ili 'oni', da će opet biti i 'mi iz Hrvatske' i 'mi iz Srbije', nadala sam se da će ovdje biti samo 'mi', odnosno vi - učesnici ovoga Skupa.“32

\section{4 .}

Iz korpusa tekstova - anketnih priloga objavljivanih u Letopisu Matice srpske te članaka napisanih povodom skupa u Novom Sadu - očito je da se jezično pitanje sredinom 1950-

\footnotetext{
24 Izuzetak su dvojica sudionika: Miloša Đurića u Novi Sad poslalo je, kako stoji u Letopisu, Udruženje prevodilaca Srbije, a Zdenka Škreba „Udruženje prevodilaca Hrvatske“, v. Letopis Matice srpske, 131/1955, knj. 375, sv. 1, 7. Njihov je udio u radu skupa posve marginalan. Prema transkriptu rasprave s novosadskog sastanka objavljenu u citiranom svesku Letopisa Đurić je govorio jedanput, a Škreb - ni toliko.

25 Letopis Matice srpske, 131/1955, knj. 375, sv. 1, 33.

26 Isto, 36.

27 Isto, 109

28 Ljudevit Jonke, „Još o odjecima i o pisanju futura I.“, Jezik, V/1956-1957, br. 4, 119.

29 Letopis Matice srpske, 131/1955, knj. 375, sv. 1, 29.

30 Radovan Lalić, „Povodom novosadskog dogovora o književnom jeziku“, Savremenik, 1/1955, 68.

31 Dalibor Brozović, „Nekoliko riječi za budućnost“, Vjesnik u srijedu (Zagreb), br. 137, 15. 12. $1954,5$.

32 Letopis Matice srpske, 131/1955, knj. 375, sv. 1, 109-110.
} 
ih vrednuje kao političko. U povodu ankete Stevanović je objavio tekst „O daljem razvoju književnog jezika kod Srba i Hrvata" u kojemu elaborira tezu o tijesnoj isprepletenosti politike i oblikovanja književnog jezika. Navodi kao neprijepornu činjenicu da su „progresivne snage“ prije stotinu godina postavile sigurne temelje „književnojezičkom jedinstvu“, koje je pogodovalo političkom ujedinjavanju, uvjeren je da će se zahvaljujući političkom jedinstvu ostvariti „u ne tako dalekoj budućnosti“ $i$ „potpuno jedinstven književni jezik“. Budući da su ta dva jedinstva - književnojezično i političko - „nedeljivo vezana“, Stevanović podsjeća jezikoslovce na to da je „doprinos ostvarenju potpunog jedinstva našeg književnog jezika od vrlo velikog značaja“. ${ }^{33}$ U kragujevačkoj Našoj stvarnosti povodom Matičine ankete ustvrđuje se da razlike u književnom jeziku Srba i Hrvata smetaju jačem zbližavanju „dva bratska naroda i kulturnom jedinstvu“, koje je prijeko potrebno u izgrađivanju socijalističke kulture. Komentator zaključuje da kad se zna od kolike je važnosti „za kulturno jedinstvo naših naroda pitanje jezika, onda je ovo ne samo kulturno, već i veliko političko pitanje“. ${ }^{34}$ Potvrde isticanja političke naravi jezičnog pitanja mogu se naći u anketnim prilozima te u raspravama u vezi s pravopisom. Smodlaka smatra da će, dođe li ikad do ujedinjavanja dvaju književnih jezika [hrvatskog i srpskog], glavnu riječ voditi politika. ${ }^{35}$ Jurković piše da sva jezična pitanja treba rješavati u otvorenoj i slobodnoj diskusiji filologa i pisaca, ali „posljednja riječ treba da bude politička, jer je i problem u svom korijenu politički“. ${ }^{36} \mathrm{Ma}-$ nje-više isti stav izriče i Lalić, pitanje „srpskohrvatskog književnog jezika nije čisto jezičko pitanje, to je pre svega političko pitanje “. ${ }^{37}$ Problem (tadašnjeg) književnog jezika Moskovljević identificira kao politički, a kad je tomu tako, onda se taj problem političke naravi mora rješavati „gde god je potrebno i mogućno, i političkim sredstvima“. 38

Da pravopis nije (tek) stručno pitanje, nije naravno otkriće rasprava vođenih 1950-ih, već još jedna potvrda da je ortografija prije svega oblik društvene akcije u koju su upletena pitanja politike i identiteta. ${ }^{39} \mathrm{~S}$ početka pedesetih konkretno je pitanje bilo treba li dokinuti pravopisno dvojstvo - na hrvatskoj strani u uporabi je Boranićev, a na srpskoj Belićev pravopisni priručnik - u korist jednoga, unificiranog priručnika. Specifična je situacija u Bosni i Hercegovini: Jovan Vuković objavio je dvije pravopisne knjige, no one nisu bile kodifikatorski priručnici, ${ }^{40}$ tako da je ondje, ako se možemo pouzdati u svjedočenje slušačice

33 Mihailo Stevanović, „O daljem razvoju književnog jezika kod Srba i Hrvata“, Naša stvarnost, VIII/1954, br. 9, 22.

34

35 6, 431

36

37

38

39

Podrobno o pravopisnim raspravama 1950-ih te o pravopisnom priručniku Matice hrvatske i Matice srpske izrada kojega je ustvrđena u Novom Sadu i povjerena „komisiji srpskih i hrvatskih stručnjaka“ v. K. MićAnović, „Pravopisne politike. Iz povijesti hrvatskoga pravopisa (1945-1960)“, u: Otpor. Subverzivne prakse u hrvatskome jeziku, književnosti i kulturi. Zbornik radova 42. seminara Zagrebačke slavističke škole (ur. Tatjana Pišković i Tvrtko Vuković), Zagreb 2014, 81-111.

40 Jovan Vuković, Pravopisna pravila i uputstva za pisanje ijekavskih glasovnih oblika sa pravopisnim rječnikom ijekavizama, Sarajevo 1949, drugo izdanje pod naslovom Pravopisna pravila ijekavskih glasovnih oblika, 1955, riječ je o knjizi pravopisnih pouka ranije objavljivanih; Pravopis savremenog našeg jezika. (Analiza pravopisnih pravila i praktična uputstva za njihovu primjenu). I dio. Upotreba velikog slova i složene riječi, Sarajevo 1952.; u knjizi se razmatraju pravopisna pravila u Boranićevu i u Belićevu pravopisnom priručniku. 
novosadskog skupa, „u pogledu pravopisa takvo šarenilo da se ne zna kako ko piše“. Hoće li se u školama pisati prema Boranićevu ili Belićevu pravopisnom priručniku postalo je "gotovo politički problem“. ${ }^{41}$

Hraste u Novom Sadu u vezi s izradom jednoga, zajedničkoga pravopisnog priručnika ustvrđuje: „Svi smo složni u tome da pitanje zajedničkog pravopisa nije strogo naučno pitanje; ono je svakako i naučno pitanje, ali je u prvom redu političko. O tome moramo voditi računa." ${ }^{\prime 2}$ Vjesnikov novinar u svojem osvrtu „na savjetovanje u Novom Sadu“ navodi da su profesori Hraste i Jonke izrekli otprilike istu misao - pravopis je „prvenstveno političko pitanje, i u tome treba biti oprezan, da ne bismo povrijedili bilo čiju osjetljivost “". ${ }^{43}$ Jonke naime političko razumijeva kao nacionalno, „mi moramo sasvim obračunati sa shvaćanjem koje je ovdje istaknuto, da se ovdje radi o jeziku i pravopisu jednoga naroda. Kada bi se ovdje radilo o pravopisu i jeziku jednoga naroda, mi se ne bismo ovdje ni sastajali“ “ ${ }^{4}$

Među srpskim jezikoslovcima u Novom Sadu Belić prihvaća tezu o političnosti pravopisa („Pitanje pravopisa je naučno i kulturno pitanje, a svakako i političko pitanje.“), no njegova interpretacija ide u drugom smjeru: jedna država i jedan pravopis („Ako smo mi jedna država, a naročito ako je naš jezik zajednički, onda ne smemo razlikama u pravopisu da to demantujemo“)..$^{45}$ Lalić je načelno prihvatio da je pravopis „, naučno i političko pitanje“, no u svojoj je elaboraciji osporio da postoji „specifični srpski ili hrvatski pravopis, jer takvih pravopisa nema“, što znači da pravopis ne može biti politički (nacionalni) problem. Kad je tomu tako, onda ne može biti ni govora o osjetljivosti Srba ili osjetljivosti Hrvata. Lalić se retorički zapitao da možda nije riječ o nacionalnoj ili nacionalističkoj osjetljivosti ili o onoj profesionalnoj. U socijalističkoj Jugoslaviji „mi smo naročito osetljivi kad je u pitanju bratstvo i jedinstvo Srba i Hrvata, i ne treba se zaklanjati za neku možda izmišljenu osetljivost da bi se branile stvari koje idu na uštrb osetljivosti u pitanju bratstva i jedinstva kod Srba i Hrvata“. ${ }^{46}$ Laliću je oponirao Marić odbacujući tvrdnju da ne postoji srpski i hrvatski pravopis, a iskazao je i razumijevanje za tuđu osjetljivost: „To nije tačno, jer su Srbi pre Prvog svetskog rata imali pravopis koji su doneli nadležni faktori u Srbiji. U Hrvatskoj je postojao pravopis koji je bio propisan od države. (...) Treba imati razumevanja za tuđu osetljivost i nikada bez velike potrebe ne treba vređati ničiju osetljivost. ${ }^{\text {“47 }}$

\section{5 .}

Hrvatski i srpski jezikoslovci sve do ankete Letopisa Matice srpske u osnovi nisu otvarali Pandorinu kutiju jezičnog identiteta. ${ }^{48}$ Milisavac je u uvodnom referatu na novosadskom

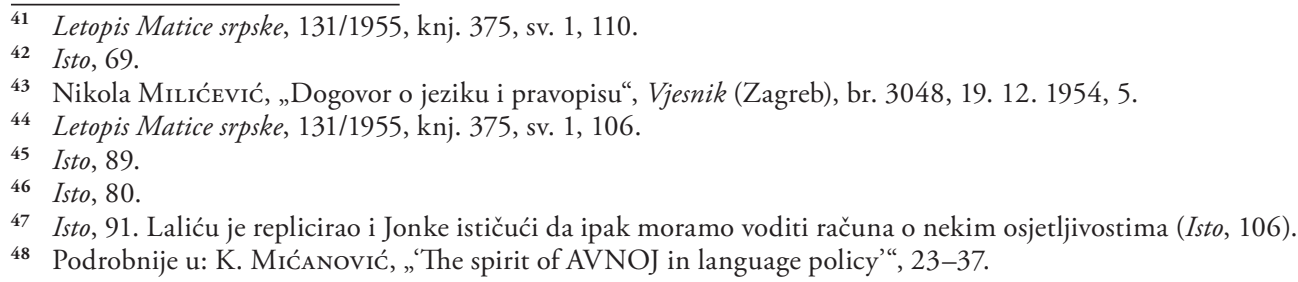


skupu, u vlastitoj interpretaciji i inventuri anketnih priloga, na prvo mjesto stavio „pitanje jedinstva jezika" u vezi s kojim se, kako je rekao, svi sudionici ankete slažu da je „to jedan i jedinstven jezik“. Pedantno je „u fusnoti“ spomenuo dvojicu autora, da je jedan iz Beograda i jedan iz Novog Sada, koji su samoinicijativno poslali anketne priloge, no njihovi članci nisu bili objavljeni u Letopisu. Ta dvojica neimenovanih autora smatrala su da je riječ „o dva posebna jezika“, što je „sankcionisala i naša nova stvarnost, federativno uređenje zemlje, - te prema tome nema nikakvog smisla cela ova anketa “. ${ }^{49} \mathrm{U}$ završnom dijelu referata Milisavac je donio zaključak u kojemu se u prvoj točki ustvrđuje:

Književni jezik Srba i Hrvata je jedinstven. Postoje izvesne razlike u jeziku dva naša najveća kulturna centra, Beograda i Zagreba, ali su one manje nego razlike između nekih krajeva jednog i istog govornog područja. Prirodni tok našeg jezika je usmeren ka još većem ujednačavanju. ${ }^{50}$

Uporište za takav zaključak Milisavac je svakako mogao naći u nizu anketnih priloga od kojih treba istaknuti Stevanovićev „Karakter razlika u književnom jeziku Srba i Hrvata“, objavljen kao prvi u rujanskom broju Letopisa Matice srpske. Srpski jezikoslovac ne niječe da postoje razlike u jeziku tih dvaju naroda, ali mu je posve neprihvatljivo da se na osnovi njih „srpski i hrvatski smatraju za dva književna jezika“. Na temelju analize primjera uglavnom uzetih iz jezika hrvatskih i srpskih književnika Stevanović zaključuje „da u jezičkom materijalu nema osnove ni za tvrdnje“ da oni „ne pišu istim književnim jezikom“ ${ }^{51}$ Po naravi stvari formulacija točke o jedinstvenom književnom jeziku ne može reprezentirati raznolikost stavova pisaca anketnih priloga, no pri njezinu oblikovanju Milisavac je posve ispustio iz vida autorske priloge u kojima se te „izvesne razlike u jeziku dva naša najveća kulturna centra" preciznije (terminološki) identificiraju i tako čine vidljivijima.

Smodlaka na nekoliko mjesta u svojem anketnom prilogu potvrđuje da postoje (ili će nastati), očito je da ni sâm zbog toga nije sretan, dva književna jezika. Uočava da se u književnim krugovima sve više gubi interes za „izjednačenje naših književnih jezika“. Zabrinut je da će se sa „srpskohrvatskim jezikom“ dogoditi, ako se nastavi s praksom da se srpski tekstovi „pretvaraju“ u hrvatske, ono što se dogodilo s „dansko-norveškim“, tj. da će od jednoga postati dva samostalna jezika. Prilog zaključuje tvrdnjom da će politika, što je već ranije ovdje spomenuto, imati glavnu riječ ako ikada dođe do „ujedinjenja naših dvaju književnih jezika “. ${ }^{2}$ Iz Barčeva članka moglo bi se iščitati da su hrvatski i srpski bili dva jezika, a da su danas dva književna jezika između kojih nema velikih razlika. Navodi da su oko 1850. hrvatski i srpski književni jezik bili „zapravo dva jezika“, a da je otada do danas uklonjen „najveći dio razlika između srpskoga i hrvatskoga književnog jezika“. Smatra da su preostale razlike u jeziku i pravopisu „smiješno malene“, a referirajući se na Stevanovićev članak, na-

49 Letopis Matice srpske, 131/1955, knj. 375, sv. 1, 11, 15.

50 Isto, 16.

51 M. Stevanović, „Karakter razlika u književnom jeziku Srba i Hrvata“, Letopis Matice srpske, 129/1953, knj. 372, sv. $3,129,138$

$52,[.$.$] namešteni su i osobiti javni službenici sa zadaćom da srpske tekstove pretvaraju u hrvatske, što oni rade zame-$ njujući istočno narečje južnim i marljivo obraćajući svaki 'srez' u 'kotar', 'duvan' u 'duhan' i. t. d.", J. SMODLAKA, „Uredništvu Letopisa Matice srpske u Novom Sadu“, 431. 
vodi da razlike koje on spominje nisu uvijek razlike „između hrvatskog i srpskog književnog jezika i pravopisa, nego više manje neke konvencije“. No za razliku od Stevanovića protivi se njihovu uklanjanju. ${ }^{53}$ Među rijetkima Pavešić jasno piše da je riječ o procesu ujednačavanja „naših književnih jezika“, dakle hrvatski i srpski identificira kao dva književna jezika. U prvoj rečenici članka navodi da razlike „između hrvatskog i srpskog književnog jezika ili, po novijoj terminologiji, razlike između književnog jezika zagrebačkog i beogradskog centra“, nisu djelo pojedinca, nego da su „nastale u toku historijskog razvitka naroda koji se danas njima služe“. ${ }^{44}$ Marić polazi od toga da je „srpskohrvatski govorni jezik“ jedan jezik te kako je prirodno da se na osnovi jednoga govornog jezika izgradi i jedan književni jezik. Smatra da bi Srbima i Hrvatima, i onda kad bi „živeli u dve različite države, i ne bi bili u dobrim odnosima“, dobro shvaćeni interesi nalagali da izgrađuju jedan zajednički književni jezik. No kad piše o razlikama, za koje ne sumnja da će se u budućnosti smanjivati, tada ipak ne piše o razlikama u jednom, zajedničkom književnom jeziku - kao što je činio Stevanović - nego se služi formulacijom (ili se ona otrgnula njegovoj misli?) o razlikama „između srpskog i hrvatskog književnog jezika“.55

U optjecaju su u anketnim prilozima osim termina književni jezik i kvazitermini kojima se nastoji precizirati narav tih „izvesnih razlika“ u ,jedinstvenom književnom jeziku“. Tako Frangeš rabi književni izraz („Hrvati i Srbi imaju jedan jezik“, ali se „Srbi služe jednim, a Hrvati drugim književnim izrazom"), ${ }^{56}$ a Matić književne upotrebe („Srbi i Hrvati imaju još dvojstvo tradicija, dvojstvo nacionalno, i zato je teško uklanjati brzim postupkom razlike između dve književne upotrebe istoga jezika"). ${ }^{57}$ Jonke u svojem prilogu izbjegava upotrijebiti sintagmu hrvatski književni jezik, što stoji u podnaslovu časopisa kojega je u to doba upravo on urednik, no osobito mu je stalo do toga da ukaže na težinu razlika u književnom jeziku kojim se služe Hrvati, Srbi (i Crnogorci) i da se jasno usprotivi njihovu uklanjanju. U članku varira konstrukcije tip (lik) književnogjezika (jedan književni jezik „dvaju, odnosno triju“ naroda, svaki narod ima „svoj tip književnog jezika“, „Hrvati i Srbi kao posebni narodi izgradili su u posljednjih stotinu godina [...] unekoliko različite tipove književnog jezika“, „jedan jezik s nekoliko likova pa svatko ima pravo da se bez neprilika služi onim, koji mu je drag"), odnosno slaže takve konstrukcije iz kojih se ipak može zaključiti da postoje dva književna jezika, i to jedan hrvatske i jedan srpske književnosti („u književnom jeziku hrvatske i srpske književnosti“, „književnosti neka nam se i dalje natječu [...] svaka u svojem izgrađenom i lijepom književnom jeziku, koji treba da podjednako volimo!“). ${ }^{58}$

U nekoliko anketnih priloga „izvesne razlike u jeziku dva naša najveća kulturna centra“ identificiraju se, što je u to doba vrlo rijetko u tada domaćoj filologiji, s pomoću pojma varijanta, koji će se postupno uobičajiti i terminologizirati te u drugoj polovici 1960-ih

\footnotetext{
53 Antun BARAC, „Jedan narod treba jednu književnost da ima“, Letopis Matice srpske, 130/1954, knj. 373, sv. 2, 106, 107.

54 Slavko Pavešrć, „[Razlike između...]“, Letopis Matice srpske, 130/1954, knj. 373, sv. 6, 439.

55 Svetislav Marić, „O našem jeziku i pravopisu“, Letopis Matice srpske, 130/1954, knj. 374, sv. 5, 351, 352.

56 Ivo Frangeš, „Budimo strpljivi“, Letopis Matice srpske, 130/1954, knj. 373, sv. 2, 117.

57 Svetozar Matić, „O latinici i o jedinstvu književnog jezika srpskog i hrvatskog“, Letopis Matice srpske, 130/1954, knj. 373 , sv. $2,101$.

58 Lj. Jonke, „Razumijevanje i snošljivost i u jezičnim pitanjima“, Letopis Matice srpske, 130/1954, knj. 373, sv. 5, 357, $358,359,362$.
} 
dospjeti u žarište polemika o književnom jeziku i njegovoj jedinstvenosti. Senić, sarajevska lektorica, opisujući jezičnu situaciju u Bosni i Hercegovini, navodi da je ujednačenost jezika - pritom misli na „zagrebačku i beogradsku varijantu srpskohrvatskog književnog jezika - toliko odmakla da se ni za koga ne može reći da je pod utjecajem „samo beogradskog, odnosno samo zagrebačkog kulturnog centra" 59 Iz Kecmanovićeva članka moglo bi se razabrati da (ipak) ne postoje varijante u srpskohrvatskom književnom jeziku, no da bi presudnu ulogu u njihovu (eventualnom) konstituiranju imao leksik. U vezi s korištenjem „srpskohrvatskog jezičnog blaga“ ustvrdio je da upravo u njemu oni kojima je stalo do toga da što više istaknu „'razlike' između 'srpskog' i 'hrvatskog' književnog jezika“ nalaze „'dokazna” sredstva za svoju teoriju o dva jezika“. Zauzimajući se za to da se piscu prepusti „slobodno korištenje leksikalnog blaga“, protestira protiv lektorskih intervencija leksičke naravi i poziva „napredne ljude“ u izdavačkim poduzećima da prestanu tolerirati „insistiranja na izvjesnim 'srpskim', odnosno 'hrvatskim', pa čak i 'bosanskim' (kalajevskim) varijantama unutar srpskohrvatskog književnog jezika“. ${ }^{60}$ Smodlaka rabi izraz varianta [sic!] kad, s već spominjanom zabrinutošću, ustvrđuje da se „sa obe strane sve češće čuju glasovi“ da su „to dva različita jezika te da treba da tako i ostane“ premda je ranije „važilo skoro kao dogma da su srpski i hrvatski književni jezik samo variante jednoga te istog jezika“. ${ }^{61}$

Lalić u svojem prilogu „O 'razlikama' u književnom jeziku Srba i Hrvata“ uglavnom raspravlja o leksičkim razlikama između „beogradske i zagrebačke varijante srpskohrvatskog književnog jezika“. U završnom dijelu teksta, osjećajući valjda da je varijanta preteška riječ koja ugrožava jedinstvenost književnog jezika, ponavlja da je književni jezik Srba i Hrvata jedan te sugerira da ,izraz 'varijanta' treba shvatiti u vrlo ograničenom i uslovnom smislu“.62 Belić u anketi također spominje varijantu, ali ne beogradsku i zagrebačku, kao što to čini Senić ili Lalić. Posve je isključena mogućnost da bi Belić u srpskohrvatskome književnom jeziku, kako ga sâm naziva, mogao vidjeti dvije varijante kad u članku ne želi ni razlikovati/ odvojiti srpske od hrvatskih književnika („u delima srpskohrvatskih književnika“, atribucija „srpskohrvatski književnici“, „srpskohrvatska književnost“ česta u monarhističkoj Jugoslaviji, posve neuobičajena u federativnoj Jugoslaviji). Izraz varijanta navodi u dvjema rečenicama kojima podsjeća na to što se zbivalo u Zagrebu neposredno prije rata:

Poznato je da je otklonjena i pomisao, koja je pokretana u Zagrebu neposredno pre rata, o pretvaranju tamošnjeg jezika u jednu vrstu varijante književnog jezika, izmenjenog pod uticajem lokalnog narodnog govora, varijante koja bi se mogla proglasiti prema potrebi i za zaseban književni jezik. Neki hrvatski pisci su sa mnogo talenta razvili tu varijantu u izvesnom pravcu i pitanje je, kako na to treba gledati. ${ }^{63}$

Belić s jedne strane na varijantu gleda, optimističan i zadovoljan, kao na prošlu stvar („Poznato je da je otklonjena i pomisao"), s druge strane, oprezan i sumnjičav, ne podcje-

59 Nada Senić, „Jedan pravopis“, Letopis Matice srpske, 130/1954, knj. 373, sv. 5, 351-355.

60 Ilija Kecmanović, „Nije dobro tolerisati netoleranciju...“, Letopis Matice srpske, 130/1954, knj. 373, sv. 5, 349, 350.

61 J. Smodlaka, „Urednišstvu Letopisa Matice srpske u Novom Sadu“, 431.

62 R. Lalić, „O 'razlikama' u književnom jeziku Srba i Hrvata“, 98.

63 Aleksandar Belić, „Povodom ankete o književnom jeziku i pravopisu“, Letopis Matice srpske, 129/1953, knj. 372, sv. 4, 237, 235. 
njuje učinak minulog rada na varijanti („pitanje je, kako na to treba gledati“). Sastavljači novosadskih zaključaka na prvo su mjesto - posve očekivano, u skladu s uvodnim referatom i s rečenim u raspravi - stavili točku o jedinstvu jezika:

Narodni jezik Srba, Hrvata i Crnogoraca jedan je jezik. Stoga je i književni jezik koji se razvio na njegovoj osnovi oko dva glavna središta, Beograda i Zagreba, jedinstven, sa dva izgovora, ijekavskim i ekavskim. ${ }^{64}$

U prvoj je točki ustvrđeno jedinstvo (,jedan“) na razini narodnog jezika, što znači na razini dijalekata kojim govore Hrvati, Srbi i Crnogorci, te ,jedinstvenost“ na razini književnog jezika. ${ }^{65} \mathrm{U}$ novosadskoj formulaciji o nositeljima narodnog jezika nije bilo mjesta za današnje Bošnjake, koji u poratnom jugoslavenskom razdoblju nisu imali status jugoslavenskog naroda (poput Srba, Hrvata, Crnogoraca, Slovenaca i Makedonaca). ${ }^{66}$ Crnogorci participiraju u narodnom jeziku, no nema ih - nema ni jednoga crnogorskog grada - kada je riječ o književnom jeziku.

Nitko na skupu nije dovodio u pitanje da je riječ o jednom jeziku: npr. „Koliko znam, svi su se učesnici u anketi složili da se radi o jednom jeziku“, sva su mišljenja u anketi, „do jednoga, da je naš jezik jedan“ (Marin Franičević); jedinstvo jezika postoji i s tim u vezi nemamo „šta da rešavamo“ (Aleksandar Belić); ne može biti „nikakve sumnje u jedinstvo našeg jezika“ (Jure Kaštelan). ${ }^{67}$ Ipak je, za svaki slučaj, Belić provjeravao „ostaje li skup i dalje pri jedinstvu jezika?“ jer se ipak „čuje da poneki smatraju da imamo dva književna jezika, a bilo je i pokušaja da se načine dva jezika“ te isticao „mislim da se svi slažemo da je iznad svega jedinstvo našeg jezika“. ${ }^{8}$

$S$ tvrdnjom o jedinstvu, o jednom narodnom jeziku, za veliku većinu bila je nespojiva tvrdnja da bi se na jednom narodnom jeziku mogla izgraditi dva književna jezika. Đuza Radović tvrdio je ne samo da ne može biti „ozbiljnog govora o dva književna jezika“ nego nije dijelio ni mišljenje Josipa Hamma koji je „dopuštao mogućnost da u književnom jeziku postoje razlike“. „Ako u pojedinim konkretnim književnim ostvarenjima postoje jezičke razlike, to je više stvar slučaja i tehnike, tako da kažem, nego nekakvog imperativa koji proizlazi iz opšteg našeg društvenog i nacionalnog zbivanja. "69 Zagrebački sveučilišni profesori Jonke i Hamm zauzimali su se za to da se u prvoj točki unese odrednica književni uz izgovor (= govor). U vezi s prvom točkom Jonke je predlagao (bez uspjeha) njezinu nadopunu, da se navede kako je to jedan jezik „sa dva književna izgovora: i ekavskim i ijekavskim“. U svojoj elaboraciji ističe „da

$\overline{64}$ Letopis Matice srpske, 131/1955, knj. 375, sv. 1, 121.

65 Lalić je u anketnom prilogu gotovo anticipirao prvu točku: „Narodni jezik Srba i Hrvata, tj. skup dijalekata kojima se govori u četiri naše republike - Srbiji, Hrvatskoj, Bosni i Hercegovini i Crnoj Gori, jedan je jezik. I književni jezik Srba i Hrvata (i Crnogoraca), u čiju je osnovu stavljen najrasprostranjeniji srpskohrvatski dijalekat, štokavski, takođe je jedinstven“, R. LaLIĆ, „O 'razlikama' u književnom jeziku Srba i Hrvata“, 89.

66 Do konca 1960-ih uglavnom je dovršen proces njihova priznavanja kao naroda pod imenom Muslimani. U rezultatima statističkih popisa navode se 1948. kao „neopredeljeni muslimani“, 1953. kao „Jugosloveni neopredeljeni“, 1961. kao „Muslimani (u smislu etničke pripadnosti)“, 1971. kao „Muslimani u smislu narodnosti“, 1980. kao „Muslimani“", v. Jugoslavija 1918 - 1988. Statistički godišnjak, Beograd 1989, 36.

67 Letopis Matice srpske, 131/1955, knj. 375, sv. 1, 26 (Franičević), 32 (Belić), 34 (Kaštelan).

68 Isto, 30, 41 (Belić).

69 Isto, 46 (Radović). 
je to jedan jedinstveni jezik sa dva različita književna izgovora“, da treba precizirati „ravnopravnost dvaju izgovora, jedan je više u upotrebi na istoku, drugi na zapadu“. $U$ formulaciju je htio ugurati „dva književna izgovora“ smatrajući da upravo književni jamči ravnopravnost ijekavskoga i ekavskoga govora. ${ }^{70}$ Hammova formulacija prve točke udovoljava Jonkeovu prijedlogu: „Jezik, kojim se služe Srbi i Hrvati, jest jedan, sa dva književna izgovora, ekavskim i ijekavskim. ${ }^{\text {"71 }}$ No u konačnici je, u prihvaćenom i potpisima ovjerenom tekstu novosadskih zaključaka, sva razlika u književnom jeziku, „koji se razvio“ oko Beograda i Zagreba, simplificirana i svedena na „dva izgovora“. U formulaciju prve točke nije ušlo ništa što bi supstancijalno moglo dovesti u pitanje jedinstvenost književnog jezika (Beograd i Zagreb samo su zemljopisne činjenice). U prvoj točki novosadskih zaključaka nema uporišta za tvrdnju da u književnom jeziku postoje dvije varijante (ili dva književna tipa ili dva književna govora). Zaključak o jedinstvenom književnom jeziku - „sa dva izgovora, ijekavskim i ekavskim“ zapravo prikladnije opisuje srpski jezični standard kakav se u jugoslavenskom razdoblju primjenjivao na području Srbije i, neznatno izmijenjen, u prvom redu ijekaviziran, izvan Srbije.

\section{6.}

Novosadski dogovor jest jezičnopolitički projekt koji je ciljao na oblikovanje jednoga književnog jezika za tri naroda - Srbe, Hrvate i Crnogorce - odnosno za područje četiriju narodnih republika - Hrvatske, BiH, Srbije i Crne Gore. No u kakofonijskoj raspravi o jeziku potaknutoj anketom i sastankom u Novom Sadu mogli su se čuti pojedinačni i (posve) manjinski glasovi koji su na različite načine poništavali dogovorenu novosadsku formulu: jedan književni jezik (u nazivu kojega se navodi srpsko i hrvatsko ime) = tri naroda $=$ četiri narodne republike.

Novinar zagrebačkoga Globusa sugerira da je potrebno zapravo raditi na ,jugoslavenskom jeziku“" koji bi trebao uključiti i Slovence i Makedonce. ${ }^{72}$ Letopis Matice srpske kroz svoj urednički filtar ne propušta dvojicu nepozvanih sudionika ankete koji pišu „o dva posebna jezika“, no propušta prilog samopozvanoga beogradskog studenta koji u futurističkom zanosu piše da je „[j]ugoslovenski jezik (...) jezik budućnosti“. Jednog će ga dana sačinjavati „srpskohrvatski, slovenački, makedonski i bugarski“, kao što će „današnja Jugoslavija s Bugarskom činiti jednu nedeljivu i kompaktnu teritorijalnu, etničku i kulturnu celinu“" ${ }^{73}$ Srpski filolog Miloš S. Moskovljević prognozira u anketi - ostajući u jugoslavenskim granicama, doduše više u mislima na Kraljevinu Jugoslaviju, negoli na FNRJ - da će se „srpskohrvatski kao opštedržavni jezik“ moći nazvati i jugoslavenskim kada se budemo manje osjećali Srbima, Hrvatima, Makedoncima i Slovencima, a više

70 „[...] jer će se u tom slučaju odlučiti i to da se na te stvari neće moći da gleda kao na neke šovinističke pojave, jer je to činjenica, to je jedan jezik, ali postoje dva književna izgovora [...]“, Isto, 40 (Jonke).

71 Isto, 93 (Hamm).

72 I. S., „Jedinstven jezik?“, Globus (Zagreb), br. 40, 18. 12. 1954, 3.

73 Jordan M. Molović, „O našem književnom jeziku i pravopisu“, Letopis Matice srpske, 130/1954, knj. 373, sv. 3, 200.

74 M. S. Moskovljević, „Za zdrav razvitak i pravilnu kulturu našeg književnog jezika“, 447. 
Jugoslavenima. ${ }^{74}$ U Novom Sadu predsjednik Matice srpske Veljko Petrović u pozdravnoj je riječi spomenuo i da je srpskohrvatski jezik „i opšti državni jezik naše federacije“ ${ }^{75}$ Takva tvrdnja nije imala uporište u Ustavu FNRJ (ostavimo ovdje po strani de facto jezičnu praksu federacije).

U novosadskoj raspravi Đurić i Moskovljević izrekli su svoj stav da su Srbi i Hrvati jedan narod. Samo je politička teza, govorio je Đurić, „da smo dva naroda“. Slikovito je objasnio da se treba raditi na tome da „ijekavski i ekavski budu hrvatski i srpski, da budu jedno, kao što se vode dva oka u jednoj glavi“, „da ćirilicu i latinicu zavole i jedni i drugi, isto tako kao što dišemo na dve bele džigerice i slušamo na dva uveta" ${ }^{76}$ Moskovljević se izjasnio da on osobno smatra „da smo jedan narod“. Na nacionalnost Srba i Hrvata gleda kao na „odnos dva fudbalska tima: jedni navijaju za jedan, a drugi za drugi tim“. Naknadno je objašnjavao da priznaje kako su Hrvati poseban narod, „to je neosporno, ali za mene lično, po mojem osećanju, Hrvati i Srbi su jedan isti narod “. ${ }^{77}$ Simptomatično je da Moskovljević nije imao potrebu priznati da su i Srbi poseban narod, što je također dovedeno u pitanje njegovim stavom da su Srbi i Hrvati jedan isti narod. Moskovljević naime implicite priznaje da se njegove riječi ,jedan narod“, „jedan isti narod“ mogu razumjeti da Hrvati nisu narod. Hrvatski sudionici sastanka nisu komentirali stav o jednom narodu - premda su nekoliko puta oštro polemizirali s Moskovljevićem ${ }^{78}$ - no od takvog se stava dvojice Srba, vjerojatno ne slučajno, ogradio srpski jezikoslovac. Stevanović je, izrijekom spominjući Moskovljevića, objasnio da se na osnovi toga što se govori o jednom jeziku ne može govoriti o samo jednom narodu, ne može se tvrditi da su Srbi i Hrvati jedan narod. Dakle, osim dvojice sudionika „niko drugi od nas tako ne misli“ ${ }^{79}$ Lalić je u osvrtu na novosadski skup tvrdnju „Srbi i Hrvati su jedan narod“ identificirao kao glasove „protivnika jedinstva našeg jezika“ koji se „na srpskoj strani javljaju u obliku vidovdanske ideologije“, „[k]onstatovati jedinstvo srpskohrvatskog jezika ne znači identifikovati srpski i hrvatski narod“ ${ }^{80}$ No posve je neuvjerljiva Lalićeva elaboracija da su pristalice „vidovdanske ideologije“ zapravo protivnici „jedinstva jezika“. Naime neodvojiv je dio ideologije integralnog jugoslavenstva jednadžba jedinstvo jezika $=$ narodno jedinstvo (npr. „Ima vrlo malo naroda u svetu kod

75 Letopis Matice srpske, 131/1955, knj. 375, sv. 1, 6 (Petrović). Vjerojatno je Lalić imao na umu i Petrovićeve riječi pišući svoj osvrt na novosadski skup: „mi ne mislimo da proglašavamo srpskohrvatski jezik za opštedržavni, a pogotovo ne mislimo da povezujemo jedinstvo srpskohrvatskog jezika za slovenačkim i makedonskim (koji je nazivan i dijalektom srpskog), kao što je to činjeno u staroj Jugoslaviji“, R. LALIć, „Povodom novosadskog dogovora o književnom jeziku“, 64.

76 Letopis Matice srpske, 131/1955, knj. 375, sv. 1, 64 (Đurić).

77 Isto, 84, 103 (Moskovljević).

78 Mirko Božić, ciljajući na Moskovljevićevo izlaganje, ustvrdio je „da mi nismo došli ovamo da se ograđujemo od ustaških i frankovačkih elemenata“ (Isto, 37), Mate Hraste više se put polemički osvrtao na Moskovljevića (Isto, 37, 38, 101), Marijan Jurković govorio je „o jednom neugodnom trenutku“, o tome kako su Božić i Hraste „mirno i dostojanstveno likvidirali ovaj incident“ misleći pritom na Moskovljevićevo izlaganje (Isto, 77), Josip Hamm branio je rad Julija Benešića od Moskovljevićevih prigovora (Isto, 92). U Novom Sadu Moskovljevića je ipak najžešće oprao Mladen Leskovac, tada član Književnog odeljenja Matice srpske, koji je svoj komentar završio rečenicom da žali „što g. Moskovljević nama ovde iznosi - uverili smo se - čitav niz netačnih informacija“ (Isto, 100).

79 Isto, 98 (Stevanović).

80 R. LALIĆ, „Povodom novosadskog dogovora o književnom jeziku“, 67, 64. O protivnicima ,jedinstva srpskohrvatskog književnog jezika i pravopisa“ Lalić je pisao u komentaru objavljenu u Borbi ciljajući pritom i na Moskovljevića. „Jedan učesnik iz Beograda napravio je čak incidenat na sastanku“, Istı, „Jedinstvo srpskohrvatskog književnog jezika i pravopisa", Borba (Beograd), br. 309, 26. 12. 1954, 6. 
kojih bi narodno jedinstvo bilo tako duboko i tako potpuno oličeno u jedinstvu jezika kao što je slučaj sa našim narodom"). ${ }^{81}$

\section{$7 \cdot$}

Provedba novosadskih zaključaka ohrabrivana je i poticana, mogu se naći potvrde u člancima i hrvatskih i srpskih autora, retorikom tipičnom za vladajući socijalistički diskurs. Dvojica pisaca anketnih priloga i sudionika sastanka u naknadnim komentarima rad na književnom jeziku dovode u izravnu vezu s ideološkom parolom „bratstvo i jedinstvo“. Radovan Lalić ustvrđuje da je jedinstvo srpskohrvatskoga književnog jezika pozitivna i progresivna stvar koja „učvršćuje jedinstvo i bratstvo Srba i Hrvata ne šteteći nimalo njihovom nacionalnom individualitetu" ${ }^{82}$ a Vuković obrazlaže da jedinstvenost književnog jezika treba uvijek poštovati i upotpunjavati „u smislu bratstva i jedinstva naših triju naroda koji se služe srpskohrvatskim jezikom". 83

Joža Horvat u članku napisanu 1955. u povodu boravka „komisije FNRJ za jezik i pravopis“ u Zagrebu ističe da je borba za jedinstven pravopis, za jedinstvenu terminologiju, za jedinstveno pismo i književni jezik sastavni dio borbe za progres na ovim prostorima naše domovine. Mi smo za „jedinstven pravopis i jedinstven srpsko-hrvatski jezik“ jer je to jedan od uvjeta „daljnjeg jačanja naše političke i društvene stvarnosti“ ${ }^{84}$ Završavajući članak o prvom sastanku Pravopisne komisije, Ljudevit Jonke piše o težnji da „se nađe pravilno i pravedno rješenje, koje će zadovoljiti i hrvatsku i srpsku javnost i biti korisno za razvitak našega književnog jezika, a i za jačanje ideje bratstva i jedinstva jugoslavenskih naroda“. Revolucionarnom hiperbolom - jezik u službi bratstva i jedinstva - poslužio se i u prvoj polovici 1960-ih da bi njome ukazao ni manje ni više nego na vrline pravopisnog priručnika („Novi pravopis jača bratstvo i jedinstvo naših naroda“). ${ }^{85}$

\section{8.}

U Novom Sadu hrvatski i srpski filolozi verificirali su partnerski odnos u izradi temeljnih standardnojezičnih priručnika: rječnika, pravopisa i terminologije. No njihov udio u cjelini jezičnopolitičke akcije koja je rezultirala novosadskim zaključcima ni u kojem slučaju

81 A. Belić, „Koliko se u našem jeziku ogleda naše narodno jedinstvo“, Naš jezik, III/1935, sv. 9-10, 264.

82 R. LALIĆ, „Jedinstvo srpskohrvatskog književnog jezika i pravopisa“, Borba (Beograd), br. 309, 26. 12. 1954, 6.

83 Jovan Vuković, „Anketa i diskusija u Novom Sadu o jeziku i pravopisu“, Oslobodenje (Sarajevo), br. $2595,30.1$. 1955, 6. Lalić govori o bratstvu i jedinstvu Srba i Hrvata, a Vuković, sarajevski profesor podrijetlom iz Crne Gore, ne imenuje ta tri naroda, no uz Srbe i Hrvate zasigurno misli na Crnogorce, a ne na „Jugoslovene neopredeljene“, ranije „neopredeljene muslimane“, kojih je prema popisu stanovništva 1953. u Bosni i Hercegovini gotovo 900.000, više od Hrvata, a manje od Srba, v. Jugoslavija 1918 - 1988, 45 (v. ovdje bilj. 66).

84 Joža Horvat, „Jedinstven pravopis neodgodivi zahtjev života“, Vjesnik (Zagreb), br. 3308, 21. 10. $1955,7$.

85 Lj. Jonke, „Prvi sastanak Pravopisne komisije“, Jezik, III/1954-1955, br. 5, 158. Članak „Novi pravopis jača bratstvo i jedinstvo naših naroda“ uvršten je u Jonkeovu knjigu Književni jezik u teoriji i praksi, Zagreb 1964, 2. izd. 1965. 
nije podjednak. Očito je to ne samo iz činjenice da su srpski filolozi okupljeni oko Letopisa Matice srpske raspisali anketu i organizirali trodnevni skup. Brojčani odnos u Novom Sadu također je davao veliku prednost srpskim (novosadsko-beogradskim) sudionicima nad hrvatskim (zagrebačkim), no brojke same po sebi nisu dokaz različitih pozicija, pa ni potvrda da je hrvatska strana bila u neravnopravnu položaju. Hrvatski filolozi u pregovore sa srpskim ušli su sa znatno manje entuzijazma, a s puno više opreza. U prilog takvoj tvrdnji mogu se navesti i članci objavljeni i prije negoli je započela novosadska akcija u kojima se tematizira pravopis - najpouzdaniji jezičnopolitički lakmus-papir. U beogradskoj Politici s početka 1953. godine povela se rasprava o pravopisu u koju se uključio i Antun Barac, prvo ime hrvatske književne historiografije, a potom i Aleksandar Belić. Iz njihovih se članaka mogu iščitati dva oprečna mišljenja o tome trebaju li Hrvati i Srbi imati zajednički pravopisni priručnik ili svatko treba, kao i dosad, imati vlastiti. Barac, tada i predsjednik Hrvatskoga filološkog društva unutar kojega se punom parom radi na izradi novoga hrvatskoga pravopisnog priručnika, objašnjavao je zbog čega sve „ujednačavanje pravopisa ne treba ubrajati među najvažnije kulturne probleme našega vremena“. Zauzeo se za to da se najprije napravi pravopis posebno na hrvatskoj, odnosno posebno na srpskoj strani, a da se poslije eventualno razmatra i „izjednačenje“ tih dvaju pravopisa. ${ }^{86}$ Dok se Barac protivi „nervozi i ubrzanosti“, nagađajući da će možda proći godina ili dvije, jedno ili dva desetljeća dok se ne provede pravopisna unifikacija, Beliću se žuri i ne može toliko čekati. U opširnu članku objavljenu ni tjedan dana nakon Barčeva piše o pravopisnom sporazumu „svih naših republika u kojima se piše srpskohrvatskim jezikom" i prikladnom socijalističkom retorikom najavljuje njegovo ostvarenje: „Danas, kada se među našim narodima sve više učvršćuje bratstvo i jedinstvo, moramo biti uvereni da vreme kada će se i o tome ozbiljno zagovoriti - nije daleko“. ${ }^{87}$ Razvoj događaja pokazao je da je Belić u veljači 1953. bio posve u pravu: vrijeme doista - nije bilo daleko. Letopis u svibnju 1953. šalje anketno pismo, u rujanskom svesku iste godine objavljuje prvi anketni prilog, u prosincu 1954. održan je skup u Novom Sadu na kojemu se razmatraju anketni prilozi i donose zaključci.

Simptomatična je i dinamika kojom su se tada najutjecajniji jezikoslovci, sveučilišni profesori s jezičnih katedara u Zagrebu, Beogradu i Sarajevu, odazvali na Matičinu anketu. Članak Mihaila Stevanovića prvi je anketni prilog, Aleksandra Belića drugi. Obojica beogradskih profesora imaju posve jasan stav o tome da je nužno unificirati književni jezik i pravopis. Sarajevski profesor Jovan Vuković objavljuje prilog u petom svesku. Potom slijede članci trojice zagrebačkih profesora s katedara za dijalektologiju, suvremeni književni jezik i za staroslavenski Filozofskog fakulteta: Mate Hraste u šestom, Ljudevit Jonke, kao profesor suvremenog jezika najpozvaniji među hrvatskim jezikoslovcima da izreče svoje mišljenje tek u devetom, a Josip Hamm, „kada se vidjelo, da se može otvoreno pisati“", 88 u jedanaestom (od ukupno petnaest anketnih nastavaka). Ne treba previdjeti ni da je tematski okvir

\footnotetext{
86 A. Barac, „Napomene uz diskusiju o pravopisu“, Politika (Beograd), br. 14426, 15. 2. $1953,7$.

87 A. Belić, „Napomene o srpskohrvatskom pravopisu“, Politika (Beograd), br. 14431, 20. 2. 1953 , 6.

88 Hamm je, analizirajući anketne priloge, ustvrdio: „Statistički - ako se sve sabere u jedno - može se reći, da je u prvih sedam svezaka gotovo polovina pisaca - što prikriveno, što otvoreno - bila sklona da prihvati ekavštinu, u drugih osam svezaka, kada se vidjelo, da se može otvoreno pisati, za takvo se rješenje nije izjasnilo ni 20\%“, Josip Hamm, „Anketa L. M. S.“, Slovo, 4-5/1955, 141.
} 
novosadske diskusije manje-više određen uvodnim referatom Živana Milisavca u kojem je odgovorni urednik Letopisa Matice srpske izdvojio osam ključnih tema: jedinstvo jezika, naziv jezika, uklanjanje „svih veštačkih prepreka“, pismo, „narečje“ (ijekavski i ekavski govor), terminologija, rječnik, jezik, pravopis. ${ }^{89}$ Aleksandar Belić, koji se prvi javio za riječ, na samom je početku taksativno, donekle mijenjajući redoslijed navedenih tema, „stavio ovim redom pitanja“: jedinstvo jezika, „[i]me jeziku“, pismo, „[n]arečje“, rječnik, pravopis, terminologija, „[u]kidanje svih prepreka u njegovu razvitku“. ${ }^{90}$ Time je uvelike trasiran smjer rasprave, ustvrđena hijerarhija tema i važnost pitanja oko kojih se vodila diskusija. U konačnici je u tekst zaključaka ušlo tih osam pitanja/tema, što su ih u svojim pripremljenim izlaganjima donijeli Milisavac i Belić.

Redakcija Letopisa Matice srpske škrto je u anketnom pismu objasnila što ju je potaknulo na raspisivanje ankete te o učinjenim predradnjama u njezinoj pripremi. U njemu stoji: „došla je na misao" da bi bilo dobro raspisati anketu „o problemima našeg književnog jezika“. Navodi se da je to i učinjeno nakon savjetovanja „sa najistaknutijim pretstavnicima književnosti, lingvista i javnog i političkog života u Beogradu i Zagrebu“.91 Redakcija nije smatrala potrebnim podrobnije objasniti motivaciju svoje akcije, nije ništa konkretnije izvijestila o tome s kojim se najistaknutijim pojedincima iz političkog života savjetovala.

Po svemu sudeći ranih 1950-ih pravopis je bio - objavljivanje Belićeva pravopisnog priručnika i užurban rad Pravopisne sekcije Hrvatskog filološkog društva na novom pravopisu hrvatskoga književnog jezika - okidač novosadske akcije. ${ }^{22}$ Treba imati na umu da su Aleksandar Belić i Mihailo Stevanović, najistaknutiji srpski jezikoslovci, imali posve jasan stav o tome da treba izraditi jedinstven pravopis za Srbe i Hrvate, pa i domišljen plan o proceduri izrade takva pravopisa kojim bi se uklonile postojeće razlike i prije negoli je uredništvo Letopisa Matice srpske razaslalo anketno pismo. ${ }^{33}$

Lalić u osvrtu na sastanak u Novom Sadu, za koji navodi da je „rezultat jednog prirodnog procesa i izraz jedne društvene potrebe“, elaborira zašto je upravo tada „stvar doista sazrela“, da se riješe pitanja „zajedničkoga srpskohrvatskog književnog jezika“, „književnog jezika Srba i Hrvata" ${ }^{94}$ Iz njegove elaboracije ne može se razabrati tko je zapravo procijenio da je stvar doista sazrela, no može se reći - na osnovi publiciranih tekstova i obrađene građe iz toga razdoblja - da su srpski filolozi, među kojima Aleksandru Beliću pripada istaknuto mjesto, obavili takvu procjenu. Nema čvršćeg uporišta za nagađanja da je filologija ispunila zadaću koju im je namijenila politika - drugim riječima, da su filolozi proveli „političku

Letopis Matice srpske, 131/1955, knj. 375, sv. 1, 10 (Milisavac).

90 Isto, 18 (Belić 18).

91 RedAKCIja Letopisa Matice srpske, „Anketa o pitanjima srpskohrvatskog jezika i pravopisa“, 125.

92 U drugoj polovici 1960-ih Stjepan Babić početak ankete Letopisa Matice srpske doveo je („Početak vjerojatno nije slučajno odabran.“) u izravnu vezu s, „vijesti o početku rada na hrvatskom pravopisu i gramatici“ (Stjepan BABIĆ, „Htijenja i ostvarenja Novosadskoga dogovora“, Jezik, XV/1967-1968, br. 1, 5). Takvu je njegovu „[s]ugestij[u] da je inicijativa za anketu LMS i Novosadski dogovor" došla zbog te vijesti odbacio Pavle Ivić u polemičkom komentaru (Pavle Ivić, „Za ravnopravnost, a protiv cepanja jezika“, Jezik, XVI/1968-1969, br. 4, 121). Milisavac je nakon 30-ak godina objašnjavao da je redakcija Letopisa došla početkom 1953. „povodom pojave Belićevog Pravopisa, na misao da sprovede anketu o jeziku i pravopisu“ (Ž. Milisavac, „O Novosadskom dogovoru“, NIN (Beograd), br. $1900,31$. 5. 1987, 4).

93 Podrobnije v. u: K. Mićanović, „Pravopisne politike“, 87.

94 R. Lalić, „Povodom novosadskog dogovora o književnom jeziku“, 63, 64. 
direktivu“ dobivenu „odozgor“ - no postoje potvrde da su se srpski filolozi u sklopu akcije potrudili pribaviti odobrenje vlasti, odnosno svojevrsnu ideološku dopusnicu. Milisavac je kasnih 1980-ih tvrdio da se nitko od političara nije miješao u rad skupa, no i da je prije negoli su pristupili poslu, što znači i prije negoli su raspisali anketu,

obavio neke konsultacije kako sa izvesnim kulturnim radnicima, tako i sa nekolicinom tadašnjih političkih rukovodilaca, iz prostog razloga da ne bismo preduzeli nešto što bi naišlo na neodobravanje i osudu. ${ }^{95}$

Urednici Letopisa Matice srpske u sklopu tih konzultacija pokucali su i na vrata Vladimira Bakarića, najutjecajnijeg političara u razdoblju socijalističke Hrvatske, ne da bi s njime raspravljali o filološkim sitnicama, nego da bi dobili placet političara koji je u proljeće 1953. i formalno i stvarno glavni predstavnik i republičke (predsjednik Izvršnog vijeća Sabora NR Hrvatske), i partijske vlasti (sekretar CK KP Hrvatske). Bakarić je u sarajevskom predavanju 1966. govorio o tome da je sudjelovao „oko tog novosadskog dogovora“, da mu je davao, „da tako kažem, podršku“. ${ }^{96}$ Nije objasnio o kakvoj je točno podršci riječ, je li ju dao kao predsjednik vlade i/ili kao partijski sekretar, no čini se - ako se možemo pouzdati u svjedočenje iz druge ruke - da su kroz ta Bakarićeva vrata i (neki) hrvatski filolozi krenuli, ili su mislili da moraju krenuti, na put u Novi Sad..$^{77}$

U drugoj polovici 1960-ih člankom Stjepana Babića „Htijenja i ostvarenja Novosadskoga dogovora" započinju hrvatski jezikoslovci kritički vrednovati učinke novosadskih zaključaka te odlazak u Novi Sad opravdavati unitarističkim pritiskom, a ondje postignuto kako-tako braniti time da je tada barem spašena ijekavica, da su zaključci ono „najviše što se u tadašnjem trenutku moglo postići“ “98 Ljudevit Jonke, ključni jezikoslovac s hrvatske strane angažiran u provedbi novosadskih zaključaka, sa sigurne vremenske distance tvrdio je da je do Novosadskog dogovora došlo „u razdoblju jakih unitarističkih težnja“.99 Gotovo istodobno, u jeku polemika o jeziku i varijantama, i Bakarić je govorio o Novosadskom dogovoru, i to vrlo suzdržano, napola kritički. No nije pokazao nikakvo razumijevanje za one koji su izjavljivali „da su tamo spasili ijekavicu“, uvjeren je da oni „nisu imali nikakvog razloga da se bilo čega boje“. Uostalom, „da 'nisu spasili' ijekavicu, mi bismo politički taj sporazum zabranili!" ${ }^{100}$ Koncem 1970 -ih objašnjavao je novinarima - jasno razdvajajući dvije strane, oni Srbi i $m i$ Hrvati - o tome da je razgovarao sa „Srbima koji su radili na 'no-

\footnotetext{
95 Ž. Milisavac, „O Novosadskom dogovoru“, NIN (Beograd), br. 1900, 31. 5. 1987, 4.

96 Vladimir BAKarić, „Razvijeni i nerazvijeni u reformi“, Oslobođenje (Sarajevo), br. 6459, 29. 5. 1966, 5.

97 Babić u članku o Bakariću piše: „Dobro se sjećam Jonkeovih riječi koje mi je on poslije jednom prilikom o tome rekao: 'Bakarić nas je ostavio na cjedilu. Da je rekao samo riječ da ne idemo u Novi Sad, ne bismo išli.'“ U istome članku citira i riječi Josipa Šentije: 'Koliko se zna, ni jedan sadašnji [sic!'] službeni politički faktor Hrvatske nije hrvatske lingviste izravno i formalno tjerao u novosadski aranžman. To se mora reći, jer to nalaže pravednost i povijesna istina. Čak je dr. V. Bakarić jednom prilikom službeno izjavio, da on u taj dogovor ne bi išao da se njega pitalo'“, $S$. BABIć, „Bakarić i hrvatski književni jezik“, Jezik, LVI/2009, br. 3, 119, 118.

98 Isti, „Htijenja i ostvarenja Novosadskoga dogovora“, 6. Prema Babićevu svjedočenju Jonke je nakon povratka iz Novog Sada „gotovo pobjedonosn[o]“ izjavio „Spasili smo ijekavicu!“, v. o tome i Istı, „Bakarić i hrvatski književni jezik“, 119.

99 Lj. Jonke, „Osnovni pojmovi o jeziku Hrvata i Srba“, Jezik, XVI/1968-1969, br. 5, 133.

100 Vladimir BAKARIĆ, Socijalistički samoupravni sistem i društvena reprodukcija. Tré́a knjiga, Zagreb 1983, 138. Rečeno u razgovoru s urednikom Televizije Beograd 11. 6. 1970.
} 
vosadskom’ pravopisu“, a nije „s našim, hrvatskim, predstavnicima“ smatrajući da je njima „stvar jasna i da nema potreba da s njima“ razgovara:

(...) a najmanje sam mislio da ih je strah od unitarističkog pritiska, a njih je bilo strah. Smatrali su da je ono što ondje neki govore direktiva koju moraju slušati, iako im nitko nije rekao da moraju slušati, onda su se najprije poplašili, pa su pristali na svašta, i kad su pristali na svašta, onda su se toga odrekli. ${ }^{101}$

\section{9.}

Sastavljači zaključaka sa sastanka u Novom Sadu ustvrdili su u sedmoj točki da zajednički jezik treba imati i zajednički pravopis izrada kojega je najhitnija kulturna i društvena potreba. Posve u skladu sa zaključkom, i posve neuobičajeno hitro i netipično za naše (akademsko) društvo, u travnju 1955. konstituirana je jedanaesteročlana Pravopisna komisija u sastav koje su ušli jezikoslovci kao predstavnici JAZU, Srpske akademije nauka, Matice hrvatske, Matice srpske, Zagrebačkog sveučilišta, Beogradskog univerziteta i Sarajevskog univerziteta. Gotovo istodobno s početkom rada Pravopisne komisije započela je polemika između Mihaila Stevanovića i Ljudevita Jonkea, prva takva u poslijeratnom razdoblju između jednoga istaknutog srpskog i hrvatskog jezikoslovca. Članci objavljivani u stručnim časopisima - zagrebačkom Jeziku i beogradskom Našem jeziku - te u beogradskoj/zagrebačkoj Borbi otkrili su da dvojica sudionika sastanka u Novom Sadu različito interpretiraju neke važne točke teksta novosadskih zaključaka u oblikovanju kojih su ondje i sami sudjelovali, i koje su svojim potpisom ovjerili. ${ }^{102}$ Polemika simptomatično ukazuje na to da krupne razlike, koje imaju težinu hrvatsko-srpskog jezičnog spora s obzirom na to da su Jonkeovi stavovi umnogome tipični za hrvatske, a Stevanovićevi za srpske jezikoslovce, nisu prestale nakon sastanka u Novom Sadu, no ona nije ni u kojem slučaju ugrozila rad na zajedničkom pravopisu. Uostalom ni njihova polemika o tome kako treba pisati futur prvi, što je bio krupan kamen smutnje, u koju su se uključili i drugi članovi Pravopisne komisije, nije prouzročila (pravopisni) raskol, nego je sve riješeno kompromisno. ${ }^{103}$

Objavljivanje zajedničkog pravopisa Matice hrvatske i Matice srpske 1960. godine - Pravopis hrvatskosrpskoga književnog jezika s pravopisnim rječnikom, Правопис српскохрватскога књижевног језика са правописним речником - identičnog pravopisnog priručnika u latiničkom i ijekavskom, odnosno u ćiriličkom i ekavskom izdanju,

$\overline{101}$ Isti, Socijalistički samoupravni sistem i društvena reprodukcija. Četvrta knjiga, Zagreb 1983, 286. Rečeno u razgovoru s novinarima 8. 11. 1978. U razgovoru „o otvorenim pitanjima jezika i sociologije“ u organizaciji Predsjedništva CK SKH govorio je slično, doduše ne birajući riječi u zatvorenom društvu: „Čak pred Novi Sad smo raspravljali i ovdje se vidi koliki su ti naši bili tamo idioti - veli: spasili smo ijekavicu. Kao da je to bilo uopće ikada u pitanju“, Hrvatski državni arhiv (dalje: HR-HDA-1002), fond Vladimir Bakarić, kut. 80.

102 Konkretne su točke prijepora u polemici Jonkea i Stevanovića naziv jezika (drugi zaključak) i „samovoljno ‘prevođenje’ tekstova“ (osmi zaključak) te s tim u vezi i pitanje o tome trebaju li se nastavnici jezično "prilagođavati sredini“ u kojoj rade. Podrobnije o polemici v. Marko Samardžija, Ljudevit Jonke, Zagreb 1990, 94-98.

103 Pravopisna komisija u konačnici je dopustila dvojak način za futur prvi (pisat ću, plest ću-čitaću, pleśću), podrobnije v. K. Mićanović, „Pravopisne politike“, 93. 
može se smatrati vrhuncem novosadskog razdoblja. U ranim 1960-ima dovršava se rukopis prvih svezaka rječnika književnog jezika Matice hrvatske i Matice srpske, izrada kojega je ustvrđena petom točkom novosadskih zaključaka, u skladu sa šestom točkom zaključaka počinju pripreme za sređivanje stručne i znanstvene terminologije. U razdoblju intenzivnih polemika - započinje Petim kongresom jugoslavenskih slavista 1965. te završava koncem 1971. - hrvatski jezikoslovci često identificiraju zaključke s novosadskog skupa kao izvorište hrvatsko-srpskog jezičnog spora u poslijeratnom razdoblju. ${ }^{104}$ Novosadski dogovor služio je kao normativan i čvrst jezičnopolitički okvir desetak godina, a rad na provedbi novosadskih zaključaka zapet će u drugoj polovici 1960-ih. Matica hrvatska na svojoj skupštini 1970. objavila je da obustavlja rad na zajedničkom rječniku s Maticom srpskom, a hrvatski jezikoslovci i književnici okupljeni u svojim strukovnim društvima u proljeće 1971. i formalno su se odrekli sporazuma postignutog u Novom Sadu.

\section{$\cos$}

\section{“One language of THE PEOPle AND A SINGLE UNIFIED STANDARD”. A SURVEY BY LETOPIS MATICE SRPSKE AND THE Novi Sad meeting}

Summary: The Novi Sad Agreement was a key event in shaping a shared, centralized language policy for the four central Yugoslav People's Republics: Croatia, Bosnia and Herzegovina, Montenegro and Serbia. The participants in the meeting that took place in Novi Sad in December 1954 put forward a ten-point conclusion: the first point states that the people of Croatia, Serbia and Montenegro speak the same language and that, therefore, the standard that developed around $\mathrm{Za}$ greb and Belgrade as its two main focal points also constitutes a single language, albeit with two pronunciations, the Ijekavian and the Ekavian. This paper provides an analysis of the attitudes of Croatian and Serbian linguists, writers and other cultural workers towards the dogma of the "single language of the people" and the "unified standard", based on the supplement titled "A survey concerning the issues of the Serbo-Croatian language and ortography" "Anketa o pitanjima srpskohrvatskog jezika i pravopisa"), as well as the proceedings of the meeting in Novi Sad, published after the fact. The paper takes into consideration the wider political context of the 1950s, specifically "the affirmation of the idea of socialist Yugoslavism", although the processes related to linguistic policies in the postwar decade are incongruent with the general process of decentralization at work in the "fake federation". In other words, these processes cannot be unambiguously applied to the field of language policies. A textual corpus is used to demonstrate that the question of language was regarded as political in the 1950s and that the implementation of the Novi Sad Agreement and its conclusions was promoted by using the kind of rhetoric typical of the political discourse of the time. Additionally, it is shown that, in the cacophony of voices participating in the discussi-

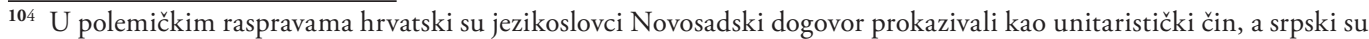
ustrajavali na tome da on „nije imao nikakav politički karakter“, odnosno da je postignut na sastanku na kojemu je „dominirao duh iskrenog bratstva i saradnje“, podrobnije v. Isti, „Jezična politika s kraja 60-ih i s početka 70-ih: u procijepu između autonomije i centralizma, u: Hrvatsko proljeće. 40 godina poslije (ur. Tvrtko Jakovina), Zagreb 2012, 282. 
on, there were certain individual ones (entirely in the minority) which attempted to go against the agreed-upon formula of "a unified standard (bearing the Serbian and the Croatian name) = three peoples = four people's republics". The Novi Sad Agreement served as the normative, solid political framework for about a decade, while its implementation came to an impasse during the latter half of the 1960s. Matica hrvatska officially ended its collaboration with its Serbian counterpart in 1970, whereas the professional associations of Croatian linguists and writers renounced the Novi Sad Agreement in 1971.

Key words: the Novi Sad Agreement, "A Survey Concerning the Issues of Serbo-Croatian Language and Orthography", language policies, the standard, orthography

\section{$\cos$}

\section{Izvori}

Hrvatski državni arhiv (HR-HDA)

HR-HDA-1002, fond Vladimir Bakarić, kut. 80.

Jugoslavija 1918 - 1988. Statistički godišnjak, Beograd 1989.

Vladimir BAKARIĆ, „Razvijeni i nerazvijeni u reformi“, Oslobodenje (Sarajevo), br. 6459, 29. 5. 1966, 4-5.

Antun Barac, „Napomene uz diskusiju o pravopisu“, Politika (Beograd), br. 14426, 15. 2. 1953, 7.

Aleksandar Belić, „Napomene o srpskohrvatskom pravopisu“, Politika (Beograd), br. 14431, 20. 2. 1953,6 .

Dalibor Brozović, „Nekoliko riječi za budućnost“, Vjesnik u srijedu (Zagreb), br. 137, 15. 12. 1954, 5 .

Joža HoRvat, „Jedinstven pravopis neodgodivi zahtjev života“, Vjesnik (Zagreb), br. 3308, 21. 10. 1955, 7.

Radovan LALIĆ, „Jedinstvo srpskohrvatskog književnog jezika i pravopisa“, Borba (Beograd), br. 309, 26. 12. 1954, 6.

Steva Marković, „Anketa o pitanjima srpskohrvatskog jezika i pravopisa“, Naša stvarnost, VI/1954, br. 3, 1, 3 .

Nikola MilıćEvić, „Dogovor o jeziku i pravopisu“, Vjesnik (Zagreb), br. 3048, 19. 12. 1954, 5.

Živan Milisavac, „O Novosadskom dogovoru“, NIN (Beograd), br. 1900, 31. 5. 1987, 4-5.

I. S., „Jedinstven jezik?“, Globus (Zagreb), br. 40, 18. 12. 1954, 3.

Jovan Skerlić, „Istočno ili južno narečje“, Srpski književni glasnik, XXXI/(16. 11.) 1913, br. 10, 756-770 + XXXI/(1. i 16. 12.) 1913, br. 11 i 12, 862-873.

\section{Literatura}

Stjepan BABIć, „Bakarić i hrvatski književni jezik“, Jezik, LVI/2009, br. 3, 115-120.

Stjepan BABIĆ, „Htijenja i ostvarenja Novosadskoga dogovora“, Jezik, XV/1967-1968, br. 1, 3-13.

Vladimir BAKARIĆ, Socijalistički samoupravni sistem i društvena reprodukcija. Treća knjiga, Zagreb 1983. 
Vladimir BAKARIĆ, Socijalistički samoupravni sistem i društvena reprodukcija. Četvrta knjiga, Zagreb 1983.

Antun BARAC, „Jedan narod treba jednu književnost da ima“, Letopis Matice srpske, 130/1954, knj. 373, sv. 2, 105-109.

Aleksandar BeLıć,, „Koliko se u našem jeziku ogleda naše narodno jedinstvo“, Naš jezik, III/1935, sv. 9-10, 257-264.

Aleksandar Belıć, „Povodom ankete o književnom jeziku i pravopisu“, Letopis Matice srpske, 129/1953, knj. 372, sv. 4, 233-237.

Enes ČEnGIĆ, S Krležom iz dana u dan (1956-1975). Balade o životu koji teče, Zagreb 1985.

Ljubodrag Dimı́́, „Ideologija i kultura u Jugoslaviji 1945-1955“, Istorijski zapisi, LXXII/1999, br. 3-4, 103-121.

Jasna Dragović-Soso, „Spasioci nacije“. Intelektualna opozicija Srbije i oživljavanje nacionalizma, Beograd 2004.

Aleksa Đilas, Osporavana zemlja. Jugoslovenstvo i revolucija, Beograd 1990.

Ivo Frangeš, „Budimo strpljivi“, Letopis Matice srpske, 130/1954, knj. 373, sv. 2, 117.

Ivo Goldstein, Hrvatska 1918-2008, Zagreb 2008.

Josip Haмm, „Anketa L. M. S.“, Slovo, 4-5/1955, 138-142.

Pavle Ivić, „Za ravnopravnost, a protiv cepanja jezika“, Jezik, XVI/1968-1969, br. 4, 118-125.

Ljudevit Jonke, „Još o odjecima i o pisanju futura I.“, Jezik, V/1956-1957, br. 4, 118-122.

Ljudevit Jonke, „Novi pravopis jača bratstvo i jedinstvo naših naroda“, Književni jezik u teoriji i praksi, Zagreb 1964, 22-24.

Ljudevit Jonke, „Osnovni pojmovi o jeziku Hrvata i Srba“, Jezik, XVI/1968-1969, br. 5, 129-134.

Ljudevit Jonke, „Prvi sastanak Pravopisne komisije“, Jezik, III/1954-1955, br. 5, 157-158.

Ljudevit Jonke, „Razumijevanje i snošljivost i u jezičnim pitanjima“, Letopis Matice srpske, 130/1954, knj. 373, sv. 5, 357-362.

Marijan Jurković, „Deseta godina...", Letopis Matice srpske, 130/1954, knj. 374, sv. 4, 241-264.

Ilija Kecmanović, „Nije dobro tolerisati netoleranciju...“, Letopis Matice srpske, 130/1954, knj. 373, sv. 5, 347-351.

Radovan LaLIć, „O 'razlikama’ u književnom jeziku Srba i Hrvata“, Letopis Matice srpske, 130/1954, knj. 373, sv. 2, 89-99.

Radovan LaLIĆ, „Povodom novosadskog dogovora o književnom jeziku“, Savremenik, 1/1955, 63 68.

Letopis Matice srpske, 131/1955, knj. 375, sv. 1, 3-126.

Svetislav Marić, „O našem jeziku i pravopisu“, Letopis Matice srpske, 130/1954, knj. 374, sv. 5, 351-361.

Svetozar Matić, „O latinici i o jedinstvu književnog jezika srpskog i hrvatskog“, Letopis Matice srpske, 130/1954, knj. 373, sv. 2, 99-101.

Krešimir MićANović, „Jezična politika s kraja 60-ih i s početka 70-ih: u procijepu između autonomije i centralizma“, u: Hrvatsko proljeće. 40 godina poslije (ur. Tvrtko Jakovina), Zagreb 2012, 271-290.

Krešimir Mićanović, „Pravopisne politike. Iz povijesti hrvatskoga pravopisa (1945-1960)“, u: Otpor. Subverzivne prakse u hrvatskome jeziku, književnosti i kulturi. Zbornik radova 42. seminara Zagrebačke slavističke škole (ur. Tatjana Pišković i Tvrtko Vuković), Zagreb 2014, 81-111.

Krešimir MićAnović, „'The spirit of AVNOJ in language policy': language policy from the end of World War II to mid-1950s in Yugoslavia and Croatia“", Socjolingwistyka, 32/2018, 23-37. 
Jordan M. Molović, „O našem književnom jeziku i pravopisu“, Letopis Matice srpske, 130/1954, knj. 373, sv. 3, 196-200.

Miloš S. Moskovıjević, „Za zdrav razvitak i pravilnu kulturu našeg književnog jezika“, Letopis Matice srpske, 130/1954, knj. 373, sv. 6, 443-450.

Slavko Pavešrć, „[Razlike između...]“, Letopis Matice srpske, 130/1954, knj. 373, sv. 6, 439-443.

Zdenko Radelić, Hrvatska u Jugoslaviji 1945. - 1991. Od zajedništva do razlaza, Zagreb 2006.

RedAKCIJa Letopisa Matice srpske, „Anketa o pitanjima srpskohrvatskog jezika i pravopisa“, Letopis Matice srpske, 129/1953, knj. 372, sv. 3, 125-126.

Marko SAMArdžIJA, Ljudevit Jonke, Zagreb 1990.

Nada Senić, „Jedan pravopis“, Letopis Matice srpske, 130/1954, knj. 373, sv. 5, 351-355.

Josip Smodlaka, „Uredništvu Letopisa Matice srpske u Novom Sadu“, Letopis Matice srpske, 129/1953, knj. 372, sv. 6, 429-431.

Mihailo Stevanović, „Karakter razlika u književnom jeziku Srba i Hrvata“, Letopis Matice srpske, 129/1953, knj. 372, sv. 3, 127-141.

Mihailo Stevanović, „O daljem razvoju književnog jezika kod Srba i Hrvata“, Naša stvarnost, VIII/1954, br. 9, 20-38.

Milan ŠIPKA, „Standardni jezik i jezička politika u Bosni i Hercegovini 1918-1970“, u: Jezik u Bosni i Hercegovini (ur. Svein Mønnesland), Sarajevo - Oslo 2005, 407-434.

Jovan Vuković, „Anketa i diskusija u Novom Sadu o jeziku i pravopisu“, Oslobođenje (Sarajevo), br. $2595,30.1$. 1955, 6, 8 .

Jovan Vuković, „Osvrt na današnje probleme našeg pravopisa“, Letopis Matice srpske, 130/1954, knj. 373, sv. 1, 4-15.

\section{Mrežna stranica}

Mario Bara, „Hrvati u Vojvodini“, Hrvatsko nacionalno vijeće u Republici Srbiji (http://www.hnv. org.rs/hrvati_u_vojvodini.php\#poslijeratno_razdoblje) 
